UDC 347.82(045)

Stephan Hobe, Prof. Dr. Dr.h.c.,

Director of the Institute of Air, Space and Cyber Law

\title{
THE EUROPEAN AVIATION POST-COVID-19 SCENARIO: OBSERVATIONS AND PERSPECTIVES
}

\author{
University of Cologne \\ Albertus-Magnus-Platz, 50923, Koln (Cologne), Germany \\ E-mail: sekretariat-hobe@uni-koeln.de
}

The goal of this article is to present the observations of the main impacts of the COVID-19 pandemic on European air transport, as well as to highlight possible scenarios and perspectives for aviation industry restoring. The article focuses on the European Union Reaction on such impacts. Besides, the article highlights outlines measures and packages to mitigate COVID-19's effects on air services. Research methods: the research was carried out using generally accepted methods of scientific knowledge, such as: analytical, comparative-legal, systemic-structural, statistics and others. Results: as a result of academic research, the main impacts of the COVID-19 on European aviation were revealed, current measures of the European Union and International organizations were outlined and post-Covid-19 scenario and perspectives in the European aviation industry were presented. Discussion: the COVID-19 pandemic impacted on European air transport and caused an unprecedented and unparalleled stall in air traffic, with an overall reduction of international passengers estimated between 50 and $80 \%$ in the first months of 2020 as compared to 2019. Besides forecasts do not predict a fast recovery, with figures indicating that only between the end of the year and the beginning of 2021, intra-EU air traffic will partially recover, with expectations of 25-30\% less aircraft movement and passengers as compared to the same months of 2019. The European Union's reaction consists in safety related measures and packages to mitigate COVID-19's effects on air services, airport slot allocation, air cargo operations, passenger protection, state aid. While some measures are likely to remain temporary in nature, some others, like airlines's vouchers, will probably need more time to be further and thoroughly addressed by the EU legislator.

Keywords: COVID-19; European aviation; extraordinary measures; air services; ground handling; air cargo operations; airport slot allocation; passenger protection; airlines' vouchers; state aid; safety related measures; EASA.

Introduction. The first months of the year 2020 have been characterised by the outbreak of an infectious disease caused by an influenza virus, belonging to the family of coronaviruses, never seen before in humans and labelled as «SARS-COV2», or more commonly «COVID-19» [1]. In actual fact, the first appearance of the latest discovered coronavirus, which among other malfunctions of the body, causes severe pneumonias, largely traces back to October/November 2019 where it rapidly spread in the Chinese megalopolis of Wuhan.

COVID-19 is not much different from previous epidemic outbreaks registered since 2000, as it be- longs to the same genus as the Severe Acute Respiratory Syndrome ( $(\langle\mathrm{SARS} »)$ ) and the Middle East Respiratory Syndrome («MERS»), which had too a significant impact worldwide [2]. However, the infection of COVID-19 has spread rapidly and widely, reaching the landmark number of almost 10 million cases worldwide. This involved, with little distinction, almost all countries of the world with over 185 countries in all continents reporting cases [3].

The global health situation has received institutional recognition, with the World Health Organization (WHO), describing it as a Public Health Emergency [4] and officially declaring it to be a pandem- 
ic on 11 March 2020 [5]. Further, most States worldwide imposing travel and social bans and restrictions [6], inducing domestic leaders, as well as international institutions to define it as possibly the worst global crisis since Second World War [7].

The Impact of the COVID-19 Pandemic on European Air Transport: Data and Facts. Air transport, in general, and European air transport, in particular, are undoubtedly among the sectors that have been hardest hit by the pandemic outbreak. As a matter of fact, the rapid diffusion of the infection throughout the European continent, along with the imposition of travel and migrations bans across all Member States of the European Union (EU) have determined an unprecedented and unparalleled stall in air traffic, with an overall reduction of international passengers estimated between 50 and $80 \%$ in the first months of 2020 as compared to 2019 [8].

As the EU air transport market is an highly densely congested environment, it shall not surprise that data from EUROCONTROL report a vertiginous fall in aircraft operation, which during the months of April, May and June 2020 has reached historic minimum levels of $-89 \%$ as compared to last year's traffic [9]. This is not only due to the rapid and uncontrolled spread of the infection, but also to the fact that social, travel and migration restrictions have made crossing border within the EU impossible. In addition, the EU itself has suspended all air traffic and movements from/to extra-EU countries, de facto closing the Union's borders as of late March 2020. This situation is gradually changing by the day as, in June 2020, the EU Commission has recommended and urged the reopening of EU borders, the reopening of the Schengen Area [10], as well as the ease of travel restrictions between EU Member States [11].

Regrettably, forecasts do not predict a fast recovery, with figures indicating that only between the end of the year and the beginning of 2021, intraEU air traffic will partially recover, with expectations of $25-30 \%$ less aircraft movement and passengers as compared to the same months of 2019. It follows, however, that these data shall also be read in conjunction with the continuous health, political and economic developments, as experts are keen on predicting that a second wave of the infection may appear globally in fall 2020.
Reactions from the European Airline Industry. The COVID-19 pandemic outbreak had - and continue to do so - unprecedented and immense social, logistic, economic and political repercussions. On a global scale, what captures the attention is the financial damage that the global airline industry is currently facing, quantified in the order of over 250 billion US dollars in the first quarter of 2020 [12]. Number are continuously growing as air traffic is still considerable below average standards. Losses do not only directly stem from the operational stall, but comprise a large number of items, including, for instance, rental payments, slot fees, airport charges, financial compensation to passengers [13].

In Europe, losses relating to the first half of 2020 are quantified in over EUR 78 billion, with several national markets severely affected (e.g. Spain, Italy and France). The reaction of EU airlines has been rather uniform, with several carriers grounding their entire fleets (e.g. Ryanair, Swiss) to counterbalance the vertiginous fall in demand and the legal restrictions to both international and extraEU operations.

The health emergency and the freeze of air operations has produced significant effects at the social level. While in some cases, air carriers have been able to maintain their staff, with pay cut and unpaid leaves [14], some others, such as British Airways [15], Air France [16] or Lufthansa [17], reached deals with their national governments to temporarily suspend thousands of their employees or to significantly reduce their working hours, some other airlines have already warned substantial redundancies and workforce dismissal [18].

The European Union Reaction: Measures and Packages to Mitigate COVID-19's Effects on Air Services. The outbreak of the COVID-19 pandemic has urged the EU to react in a comprehensive and harmonious manner. In the area of air transport, the EU possibly faced one of its biggest challenges since the three regulatory packages of liberalisation of air services, adopted in the years 1987-1992, established a true single EU internal aviation market [19].

In this light, the European Commission, also upon requests and recommendations coming from EU airlines and industry associations, has been carefully attentive of the factual and political development 
and has promptly addressed a variety of critical issues.

Airport Slot Allocation. The first intervention relates to the area of slot allocation. This area is governed by Regulation (EC) No. 95/93 providing common rules on slot allocation at EU airports [20]. According to this Regulation, airlines shall use at least $80 \%$ of their take-off and landing slots in order to be granted the right to use the same slot in the following year [21]. This industry practice is also known as 'grandfathering rights' or ' $80 \%$ rule' [22]. Given the discussed travel restrictions and the stall in air operations, doubts and concerns pertaining to the application of such provision rapidly arose within the aviation community. As early as 2 March 2020, the International Air Transport Association (IATA) and the Airports Council International (ACI) urged regulators and requested that rules governing slot allocation be suspended for the year 2020 as the application of the $« 80 \%$ rule» during such historic months would be inappropriate and would not reflect the extraordinary nature of the global social and economic scenario [23].

Welcoming the industry recommendations, and acknowledging the extraordinariness of the pandemic outbreak, on 30 March 2020, the EU adopted a Regulation formally amending the above referred EU legal regime for slot allocation [24]. The legislative measure establishes a temporary framework applicable until 24 October 2020 (but a final evaluation on the duration of these extraordinary measures will be made on 15 September 2020), which following the proposals from the European Commission [25], suspends the application of the airport slot requirements as per Regulation (EC) No. 95/93 and provides a waiver for all EU airlines with respect to the $80 \%$ rule.

Provision of Air Services within the Union. The regulation of air services in the EU is contained in the Regulation (EC) No. 1008/2008, which provides basic rules as to freedom of establishment of airlines [26]. This legal regime has in fact revolutionised the provision and the structure of air traffic in Europe, as it introduced the notion of «Community (now Union) air carrier» [27] and de facto abolished the reserve of cabotage [28] in the entire territory of the Union.
Notably, among the requirements set out for the issuance of EU air operator licenses, the Regulation requires air carriers to demonstrate a solid financial stability and viability [29]. On these grounds, Member States may revoke or suspend the operating licence of any air carrier, which may not be able to fulfil its financial obligations in the next twelve months. Since such financial requirement is deemed to conflict with the financial crisis stemming from the COVID-19 pandemic, the EU promptly intervened, accepting the numerous recommendations of the European Commission [30], by temporarily amending Regulation (EC) No. 1008/2008 [31]. The temporary framework not only suspends the application of the financial conditions for EU air carriers, but also introduces a section relating to "emergency measures relating to COVID-19" designed to simplify mechanisms and procedures, as well as provides for the automatic renewal of all ground handling contracts currently in force until December 2021.

Air Cargo Operations. On 26 March 2020, the European Commission issued a Communication providing guidelines for the operation of air cargo services within and from/to the EU [32]. In particular, it is stressed that air cargo plays a vital role in the quick delivery of essential goods, medicines, medical equipment and supplies, organs or other substances of human origin.

The adopted measures aim at facilitating and simplifying procedural aspects connected to the operation of air cargo services. More specifically, the measures include the temporary removal of night curfews or slot restrictions at airports for essential cargo operations, facilitating the use of passengeronly aircraft for extraordinary cargo operations, ensuring that staff working in the cargo industry are qualified as critical personnel during lockdowns and emergency measures and encouraging that cargo operations will reserve capacity for the transportation of essential and/or medical equipment or cargo.

Passenger Protection. The diffusion of the infection of COVID-19, along with the numerous travel and migration restrictions imposed globally and in Europe resulted in a completely unprecedented situation whereby most EU airlines cancelled their entire schedules. This determined a 
never-seen before amount of cancelled flights within the EU, with consequently huge repercussions for both airlines and customers.

The EU is one of the few world's regions having a systematic legal regime concerning air passenger rights. This is outlined in the text of Regulation (EC) No. 261/2004, which provides assistance and monetary compensation in cases of denied boarding, long delay and flight cancellation [33].

The reaction of EU airlines to the immense number of flight cancellations has been that of offering customers digital monetary vouchers, usually of the amount corresponding to the ticket price paid by the passenger. Vouchers generate benefits for airlines as not having to reimburse passengers, they do not have to suffer liquidity difficulties. Also, offering a voucher is a rather convenient instrument, as the voucher can exclusively be spent with the relevant airline, ensuring therefore continuity of scheduling and capacity.

The use of monetary voucher, however, has raised significant concerns and issues both within the industry and in the opinion of EU institutions. Voucher are, indeed, not formally encompassed by Regulation (EC) No. 261/2004 and represent a sui generis practice, which has developed within the industry itself. A debate has recently emerged on the validity of vouchers offered by the carriers, particularly in light of their compatibility with the regime of Regulation (EC) No. 261/2004. On this issue, in an attempt to clarify the matter, the European Commission, as early as March 2020, has issued interpretative guidelines on the application of the EU passenger rights regime (Regulation (EC) No 261/2004) during the COVID-19 pandemic [34].

The matter has been further clarified in May 2020 with the European Commission adopting a recommendation through which it reaffirms that vouchers that carriers offer to passengers shall be an alternative to reimbursement in money, as the passenger shall at all times be free to choice what whether he/she intends to voluntarily accept the voucher in the place of monetary compensation as provided by Regulation (EC) No. 261/2004 [35].

In the area of passenger protection, future perspectives are not easy to identify. In fact, Regulation (EC) No. 261/2004 has already undergone crit- icism and revision procedure and the aviation community at large is invoking some more flexible instruments and a more balanced approach. Early speculations also seem to indicate that vouchers could possibly enter the legal regime by way of a new revised Regulation so as to provide flexible instruments and emergency responses.

State Aid. State aid is usually a rather delicate and sensitive matter, comprising social, economic and political opportunities and consideration. It should not come as a surprise, therefore, that the tremendous economic impact of the current COVID-19 pandemic has early triggered compelling substantial doubts and issues.

As a matter of fact, the EU (international) airline industry has witnessed a truly unprecedented crisis, with moments of complete stall in not only operations, but also naturally in income. As a result, most of the carriers are currently facing difficulties and financial instability, firmly invoking, along with the industry associations, such as IATA or Airlines for Europe (A4E) that governmental financial intervention by means of aid or direct grants is fundamental for the survival of the entire industry [36].

State aid regulation has been one of the first areas in which the EU intervened since the outbreak of the pandemic. On 19 March 2020, the European Commission issued a Communication establishing a temporary framework for State aid measures to support the economy in the current COVID-19 outbreak [37]. This forms part of the broader coordinated economic response that the EU has promoted against the negative effects of COVID-19 on the Union's economy [38].

The temporary framework makes it possible to consider certain State aid as compatible with the internal EU market in application of the provisions of Art. 107 of the Treaty on the Functioning of the European Union (TFEU) [39]. This framework essentially enables and allows States to provide financial support in the form of direct grants, guarantees and loans channelled through credit institutions, banks or financial institutions or taxation relief to support undertakings facing shortage or unavailability of liquidity, provided that the measure meets certain conditions. Among others, main conditions require that the aid shall be granted by 31 December 2020 and to undertakings that were 
not already in financial difficulties at the date of 31 December 2019.

State aid in the EU airline industry is not a new phenomenon, as many large airlines (legacy carriers) have benefitted from significant State financial aid in the last decades, often raising doubts and concerns as to their respect of the requirements set out under Art. $107 \mathrm{ff}$ of the TFEU [40]. Currently, there have been discussion practically in every Member State concerning the possibility to grant governmental financial aid to national airlines. For instance, the German government and the French/Dutch governments have been negotiating with their national air carriers, Lufthansa and Air France/KLM, huge aid of about EUR 9.8 billion and 7.7 billion, respectively. In the same light, the Italian government took a public stake in the company business structure of the national carrier, Alitalia, raising its previous participation from $25 \%$ to over $75 \%$.

While the European Commission seems to be favourable to this scenario, with a highly likely chance that it will approve large State aid to airlines, criticism and legitimate doubts have been raised by a number of EU air carriers, for instance low-cost carriers such as Ryanair and Easyjet, which have announced that they will challenge the above financial grants in application of the norms of EU competition law and on the basis that aid are discriminatory in nature - as they are strategically granted only to some airlines - and have a discriminatory effect on the fair competition or level playing field dogma, which has characterised the last 20 years of the EU's action in the field of internal and external air transport relations.

Safety Related Measures: the Role of the European Aviation Safety Agency. In addition to the political measures adopted by the European Commission in the area of air transport, one shall not disregard that the European Union Aviation Safety Agency (EASA) has also taken active response to the COVID-19 pandemic in the field of technical and safety of air travel.

Besides postponing the entering into force of Regulation (EU) No. 2019/947 in the area of unmanned aircraft operation [41], which is now expected to take effect as of 1 January 2021, EASA has issued relevant and helpful guidance material in the areas of: (i) crew member qualification, training and licensing, providing for some temporary modifications and exemptions relating to licensing [42]; and (ii) aircraft operation at large, providing a Health Safety Protocol [43], which details requirements, procedures, checks and measures that both operators (e.g. air carriers), personnel and passengers shall observe. These include, for instance, the wearing of face masks when on board aircraft or within airport facilities, the obligation to disinfect aircraft's interior before and after every operation, as well as more specific security screening at airports (e.g. temperature check; social distancing).

Conclusion. At the time of writing, the European aviation industry is slowly restarting operations. Forecasts predict that, although slight and timid signs of recovery will increase in summer 2020, intra-EU air traffic will still be well below-average until the end of 2020.

The COVID-19 pandemic has demonstrated that rapid and vertiginous changes in the normal aircraft operations and, more generally, to the usual global political and transport scenario, do require swift regulatory and political adaptations as, for instance, the airline industry is naturally linked to social and political development on a much larger scale. The EU's response to the vertiginous fall in demand has been significant, but whether new initiatives will be necessary to support the aviation and airline industries will very much depend on the development of the diffusion of the pandemic outbreak, as well as on the political measures that will be adopted at the national level by Member States.

While some measures are likely to remain temporary in nature, some others will probably need more time to be further and thoroughly addressed by the EU legislator. For instance, areas such as passenger rights and State aid are likely to continue producing their effects in the next months and, consequently, the Union will evaluate whether to extend, renew - or even make some temporary amendments more permanent (e.g. vouchers).

\section{References}

1. The present article adopts the terminology «COVID-19». 
2. See N. Petrosillo et al, «COVID-19, SARS and MERS: Are They Closely Related?», Clinical Microbiology and Infection (March 2020).

3. URL: https://www.worldometers.info/ coronavirus/ (last access 22 June 2020).

4. URL: https://www.who.int/who-documentsdetail/covid-19-public-health-emergency-ofinternational-concern-(pheic)-global-research-andinnovation-forum (last access 22 June 2020).

5. URL: https://www.who.int/dg/speeches/ detail/who-director-general-s-opening-remarks-at-themedia-briefing-on-covid-19-11-march-2020 (last access 22 June 2020).

6. Travel and immigration bans and restrictions are introduced or amended on a constant basis. The International Air Transport Association (IATA) provides an up-to-dated list of all travel restrictions at: https://www.iatatravelcentre.com/ internationaltravel-document-news/1580226297.htm (last access 22 June 2020).

7. URL: https://www.telegraph.co.uk/news/2020 /06/19/angela-merkel-warns-coronavirus-willtrigger-worst-recession/ (last access 22 June 2020).

8. URL: https://www.icao.int/sustainability/Doc uments/COVID-19/ICAO_Coronavirus_Econ_Impact.pdf (last access 22 June 2020).

9. URL: https://www.eurocontrol.int/covid19 (last 22 June 2020).

10. The Schengen Area is an area, established in 1985 , comprising 26 countries that have formally abolished all passport and other types of border and migration control at their mutual borders. The area functions as a single jurisdiction for travel purpose, with a common visa policy. The Area currently comprise 22 EU Member States and 4 non-EU Members (Iceland, Norway, Switzerland and Lichtenstein). As of today, the regulation concerning the use of the Schengen Area has been consolidated by way of the so-called Schengen Borders Code. See, Regulation (EU) No. 2016/339 of the European Parliament and of the Council of 9 March 2016 on a Union Code on the rules governing the movement of persons across the borders (Schengen Borders Code), OJ L 77, 23.3.2016, 1-52.

11. URL: https://ec.europa.eu/commission/ presscorner/ detail/en/ip_20_823 (last access 22 June 2020).
12. Id. See also, https://www.iata.org/en/ press$\mathrm{room} / \mathrm{pr} / 2020-04-14-01 /$ (last access 22 June 2020).

13. See, https://www.nortonrosefulbright.com/ de-de/wissen/publications/ 895cf 5ba/covid-19-andthe-practical-implications-for-the-global-aviationindustry (last access 22 June 2020).

14. URL: https://www.theguardian.com/ business/2020/may/01/ryanair-cut-jobs-coronavirusgrounds-flights-restructuring (last access 22 June 2020).

15. British Airways has reached a deal to temporarily suspend more than 30,000 of its cabin crew and ground staff. The airline, which has grounded most of its fleet due to the coronavirus, has been locked in talks with unions for more than a week. Under the jobs retention scheme, the government funds $80 \%$ of someone's salary capped at a maximum of $£ 2,500$ a month. But union Unite said there would be no cap on earnings under its agreement with BA. The union also said no BA staff would be made redundant during the coronavirus crisis. See, https://www.bbc.com/news/business-52130021 (last visit 22 June 2020).

16. In the months of March and April 2020, Air France has gradually reduced its activities up to $90 \%$ and, consequently, temporarily laid off or suspended $80 \%$ of its workforce. See, https://www. aerotime.aero/clement.charpentreau/24679-airfrance-to-temporarily-lay-off-80-of-staff-due-tocoronavirus (last access 22 June 2020); https://www.franceinter.fr/economie/crise-ducovid-suppressions-d-emplois-en-perspective-chezair-france-qui-subit-de-lourdes-pertes (last access 1 June 2020).

17. Lufthansa reached agreements with its works council and trade unions to introduce short-time working for at least 27,000 cabin and ground staff in Frankfurt and Munich. It also said that members of the executive board had waived $20 \%$ of their compensation in solidarity with all employee group. The company's CEO Carsten Spohr said in remarks posted on the German aviation group's website on Friday. «We are fighting for the future of this company and the future of the roughly 130,000 employees of the Lufthansa Group in what is currently the greatest challenge of our recent history». See, https://www.reuters.com/article/us-healthcoronavirus-lufthansa-jobs/two-thirds-of- 
lufthansas-staff-to-shorten-work-hours-due-tocoronavirus-idUSKBN21J4FM (last access 22 June 2020); https://www.spiegel.de/ consent-a-?target Url=https\%3A\%2F\%2Fwww. spiegel.de\% 2Fwirt schaft $\% 2$ Funternehmen $\% 2$ Fcoronavirus-lufthansaschickt-87-000-mitarbeiter-in-kurzarbeit (last access 22 June 2020).

18. Virgin Atlantic has announced its intention to cut 3000 jobs in the UK and to end its operations at London Gatwick Airport, while applying for emergency loan from the Government. See, https://www.bbc.com/news/business-52542038 (last access 1 June 2020). Similarly, Lufthansa, Air France, Alitalia and almost all major EU air carriers have announced restructuring plans designed to considerably reduce the number of their employees.

19. On the liberalisation of air services in the EU, see, generally See, among others, Stephan Hobe, Nikolai von Ruckteschell and David Heffernan (eds.), Cologne Compendium on Air Law in Europe, (Carl Heymanns, 2013), 221-223; Pablo Mendes De Leon, Introduction to Air Law, Tenth Edition, (Kluwer Law International, 2017), 96-99.

20. Council Regulation No. 95/93 of 18 January 1993 on common rules for the allocation of slots at Community airports, OJ L 14, 22.1.1993, 1-6.

21. Pursuant to Art. 10 (3) of the Regulation: «Slots which are allocated to an air carrier for the operation of a scheduled service or a programmed non-scheduled service on a particular moment of a day and for the same day of the week over a recognizable period up to one scheduling period shall not entitle that air carrier to the same series of slots in the next equivalent period, unless the air carrier can demonstrate to the satisfaction of the coordinator that they have been operated, as cleared by the coordinator, by that air carrier for at least $80 \%$ of the time during the period for which they have been allocated».

22. See, in literature, Christoph Naumann, «New Proposal to Amend the System of Airport Slot Allocation in the European Union», 37 Air \& Space Law 3 (2012), 185-211; Katja Brecke, «Airport Slot Allocation: Quo Vadis, EU?», 36 Air \& Space Law 3 (2011), 183-200.

23. URL: https://www.iata.org/en/pressroom/pr/ 2020-03-02-01/ (last access 22 June 2020); https://www.aci-europe.org/media-room/237- statement-on-iata-s-requested-suspension-of-slotrules-due-to-the-covid-19-outbreak.html (last access 22 June 2020).

24. Draft Regulation (EU) No. 2020/46 of the European Parliament and of the Council of 30 March 2020 amending Council Regulation (EEC) No. 95/93 on common rules for the allocation of slots at Community airports, PE-CONS $4 / 1 / 20$.

25. Communication from the European Commission, Proposal for a Regulation of the European Parliament and of the Council amending Regulation (EC) No. 95/93 on common rules for the allocation of slots at Community airports, $\operatorname{COM}(2020) 111$ Final, (13 March 2020).

26. Regulation (EC) No. 1008/2008 of the European Parliament and of the Council of 24 September 2008 on common rules for the operation of air services in the Community, OJ L 293, 31.10.2008, 3-20.

27. Art. 2 (11) of Regulation (EC) No. 1008/2008 clarifies that «Community air carrier' means an air carrier with a valid operating licence granted by a competent licensing authority in accordance with Chapter II».

28. On the notion of cabotage in air transport, see, for instance, Pablo Mendes De Leon, Cabotage in Air Transport Regulation, (Martinjus Nijhoff Publishers, 1992).

29. Art. 5 of Regulation (EC) No. 1008/2008.

30. Communication from the European Commission, Proposal for a Regulation of the European Parliament and of the Council amending Regulation (EC) No. 1008/2008 of the European Parliament and of the Council on common rules for the operation of air services in the Community in view of the COVID-19 pandemic, COM(2020) 178 Final, 29.4.2020.

31. Regulation (EU) No. $2020 / 696$ of the European Parliament and of the Council of 25 May 2020 amending Regulation (EC) No. 1008/2008 on common rules for the operation of air services in the Community in view of the COVID-19 pandemic, OJ L 165, 27.5.2020, 1-6.

32. Communication from the European Commission, European Commission Guidelines: Facilitating Air Cargo Operations during COVID-19 outbreak, COM (2020) 2010 Final, 26.3.2020. 
33. Regulation (EC) No. 261/2004 of the European Parliament and of the Council of 11 February 2004 establishing common rules on compensation and assistance to passengers in the event of denied boarding and of cancellation or long delay of flights, and repealing Regulation (EEC) No. 295/91, OJ L 46, 17.2.2004, 1-8.

34. Communication from the European Commission, Commission Notice Interpretative Guidelines on EU passenger rights regulations in the context of the developing situation with COVID-19, COM (2020) 1830 Final, 18.3.2020.

35. European Commission Recommendation of 13 May 2020 on vouchers offered to passengers and travellers as an alternative to reimbursement for cancelled package travel and transport services in the context of the COVID-19 pandemic, C(2020) 3125 Final, 13.5.2020.

36. The IATA predicted that the worst may still yet to come for the airline industry. Acknowledging that Many European governments have recognized the strategic importance of their aviation industries and provided support, the IATA firmly remarks that much of the financial aid has been in the form of loans, which are adding to the debt burden for airlines and which will hinder their ability to invest in new services, cleaner aircraft, and expanded employment going forward. See, https://www.iata. org/ en/pressroom/pr/2020-06-18-01/ (last access 22 June 2020).

37. Communication from the European Commission, temporary framework for State aid measures to support the economy in the current COVID-19 outbreak, C(2020) 1863 Final, 19.3.2020. The Commission notes that: «undertakings may not only face insufficient liquidity, but they may also suffer significant damage because of the COVID-19 outbreak. The exceptional nature of the COVID-19 outbreak means that such damages could not have been foreseen, are of a significant scale and hence put undertakings in conditions that sharply differ from the market conditions in which they normally operate. Even healthy undertakings, well prepared for the risks inherent to the normal course of business, can struggle in these exceptional circumstances, to such an extent that their viability may be undermined».

38. Communication from the European Commission, coordinated response to the COVID-19 outbreak, COM(2020) 112 Final, 13.3.2020.

39. Consolidated version of the Treaty on the Functioning of the European Union, OJ C 326, 26.10.2012, 47-390.

40. See, for example, Pablo Mendes De Leon, Introduction to Air Law, Tenth Edition, (Kluwer Law International, 2017).

41. See, Commission Implementing Regulation (EU) No. 2019/947 of 24 May 2019 on the rules and procedures for the operation of unmanned aircraft, OJ L 152, 11.6.2019, 45-71.

42. European Union Aviation Safety Agency (EASA), EASA Guidelines - COVID-19: Guidance on the maintenance of crew members in relation to the COVID-19 pandemic, 26.3.2020

43. European Union Aviation Safety Agency (EASA) and European Centre for Disease Prevention and Control (ECDC), COVID-19 Aviation Health Safety Protocol: operational guidelines for the management of air passengers and aviation personnel in relation to the COVID-19 pandemic, 21.5.2020. 
Штефан Хобе

\title{
ЄВРОПЕЙСЬКИЙ АВІАЦІЙНИЙ ПОСТ-СОVID-19 СЦЕНАРІЙ: СПОСТЕРЕЖЕННЯ ТА ПЕРСПЕКТИВИ
}

\author{
Кельнський університет \\ площа Альберта Магнуса, 50923, Кельн, Німеччина \\ E-mail: sekretariat-hobe@uni-koeln.de
}

\begin{abstract}
Мета иієї статті полягає у висвітленні спостережень основних наслідків пандемії COVID-19 на європейський повітряний транспорт, а також окресленні можливих сиенаріїв та перспектив відновлення авіаційної галузі. Стаття зосереджена на реакиії Європейського Союзу на такі наслідки. Крім того, у статті представлені заходи та пакети для пом'якшення впливу COVID-19 на повітряне сполучення. Методи дослідження: дослідження проводилось із застосуванням загальновизнаних методів наукового пізнання, таких як: аналітичний, порівняльно-правовий, системно-структурний, статистичний та інші. Результати: в результаті академічних досліджень було виявлено основні впливи COVID-19 на європейську авіачію, окреслено поточні заходи Європейського Союзу та міжнародних організацій та представлено сценарій та перспективи розвитку в Свропі після COVID-19. Обговорення: пандемія COVID-19 вплинула на європейський повітряний транспорт $і$ спричинила безпрецедентну зупинку повітряного руху, із загальним скороченням міжнародних пасажирів у 50-80\% у перші місящі 2020 року порівняно з 2019 роком. Відповідно до прогнозів швидкого відновлення не слід чекати, иифри вказують на те, щяо лише між кінцем року та початком 2021 року повітряний рух всередині СС частково відновиться, очікуючи на 25-30\% менше руху літаків та пасажирів порівняно з тими ж місяиями. Реакиія Свропейського Союзу полягає у заходах, пов'язаних із безпекою, для пом'якшення впливу COVID-19 на повітряне сполучення, розподілу слотів у аеропортах, авіаційними вантажними перевезеннями, захистом пасажсиів, державною допомогою. Хоча деякі заходи, ймовірно, залишатимуться тимчасовими за своєю суттю, деякі інші, ймовірно, потребують більше часу для подальшого і ретельного розгляду законодавиями $Є C$, такі, наприклад, як ваучери авіакомпаній.
\end{abstract}

Ключові слова: COVID-19; Європейська авіачія; надзвичайні заходи; авіачійні послуги; наземне обслуговування; авіаційні вантажні операџії; розподіл слотів у аеропорту; захист пасажирів; ваучери авіакомпаній; державна допомога; заходи, пов'язані з безпекою; EASA. 